\title{
Accuracy of Actual Weight Measurement Using Upper arm Circumference in South Sulawesi Ethnics
}

\author{
Citrakesumasari Citrakesumasari ${ }^{1}$, Yessy Kurniati ${ }^{2}$, Andi Imam Arundhana ${ }^{1}$, Abdul Salam $^{1}$ \\ ${ }^{1}$ Nutrition Science Study Program, Faculty of Public Health, Hasanuddin University, Makassar, Indonesia; ${ }^{2}$ Public Health Study \\ Program, Faculty of Medicine and Health Sciences, Universitas Islam Negeri Alauddin, Makassar, Indonesia
}

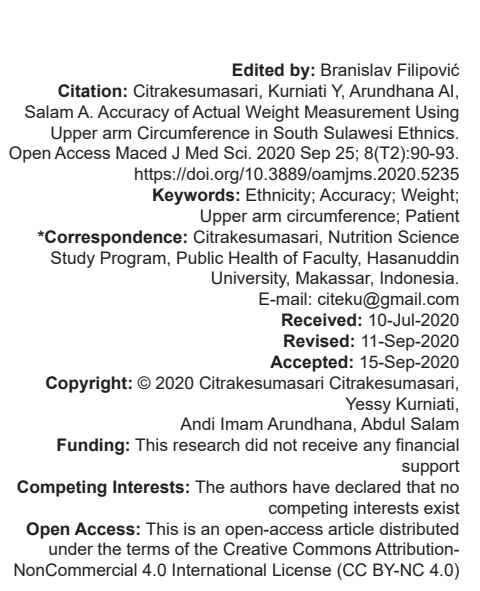

\begin{abstract}
BACKGROUND: Assessment of nutritional status in hospital patients is important to do. However, due to the patient's condition, the measurement must use an estimation formula. This study wanted to know the accuracy of the measurement of body weight from the formula commonly used in hospitals.

AIM: This study wants to see how accurate the actual body weight predictions are based on measurements of UAC in the ethnics in the province of South Sulawesi.

METHODS: The design of this study was cross-sectional. The population of this study was young adults aged 20-29 years. Number of sample is 896 respondents. Sampling consists of 2 stages, namely sample area and research sample. The sampling used was systematic random sampling. The sample size in this study was calculated using the Stanley Lemeshow formula.

RESULTS: The results showed that the formula used to predict the patient's weight, if the formula is calculated using the formula 100\% Patient Upper Arm Circumference (PUAC), it is suitable for ethnic Bugis and Mandar male. The formula $90 \%$ PUAC is suitable for ethnic Bugis and Mandar and male ethnic Makassarese and Toraja. The formula $85 \%$ is suitable for women for all ethnicities.

CONCLUSION: It can be concluded that the accuracy of measuring body weight depends on gender and ethnicity so it is expected that health practitioners in the hospital can adjust the use of formulas according to gender and ethnicity.
\end{abstract}

\section{Introduction}

Assessment of the nutritional status of hospitalized patients in hospitals is currently difficult because of the condition of patients who have to lie in bed. Adult and child patient body weight is usually difficult to measure before being given first aid/ intervention [1]. Based on secondary data from Wahidin Sudirohusodo Hospital, from all patients in SeptemberDecember 2015 , only new patients who could measure their weight were only $23.33 \%$. Some studies found that nearly $47 \%$ of patients who had just been admitted to hospital were suffering from malnutrition, and after being treated would increase to $69 \%$ [2]

Body weight is needed in the assessment of nutritional status, and determining the nutritional needs of patients. Measurement of body weight every week is an objective parameter, but what is an obstacle is that not all patients treated can be measured in body weight by weight scales. Weight has a relationship with other measurements, such as upper arm circumference (UAC) and body mass index (BMI). Several studies have shown that weight has a very strong relationship with UAC and BMI [3]. With this very strong relationship, weight, UAC, and BMI have the ability to be used as predictors of nutritional status [4].

Research on patients at Stanford University Hospital, San Francisco, United States, has obtained prediction results for UAC predictors and knee height [1]. In addition, there is a formula for predicting body weight from the calculation of combined knee height and UAC for blacks and whites. In China, studies have been conducted to predict body weight from the calculation of combined UAC and hip circumference. These formulas cannot be used as standards for Indonesia because the formula used is the result of research using samples that are physically different from Indonesian people [1].

In Indonesia, research has been carried out in the Nutrition Installation of the DR Hospital. Cipto Mangunkusumo for 1 week with a sample of adult age 19-56 years by obtaining formula equations in adults based on UAC with hip circumference and based on UAC with knee height to predict body weight. WHO stressed that adjustments to anthropometric standards in a country must be based on the results of research in the country concerned so that it is necessary to obtain an appropriate formula for Indonesian people. In the 
context of ethnic and cultural diversity, each province in Indonesia certainly has its own ethnic characteristics and culture. One of them is South Sulawesi, which is a province in Indonesia, located in the southern part of the island of Sulawesi, with Makassar City as the capital. In general, there are four ethnic groups in the province of South Sulawesi, namely the Bugis, Makassar, Toraja, and Mandar Ethnics [5].

This study wants to see how accurate the actual body weight predictions are based on measurements of UAC in the ethnics in the province of South Sulawesi.

\section{Materials and Methods}

The research design was cross sectional. The study population was young adults aged 20-29 years. The sample in this study was partly young adults aged 20-29 years. The sampling method consists of 2 stages, namely the sample area and the research sample. To determine the area in this study, the method used to determine the selected District. District and Village was purposive sampling with reasons that represent the characteristics of the area. The sampling used was systematic random sampling. Systematic sampling by dividing the number or members of the population by the specified sample size. So that the sample is obtained according to the calculation results.

Samples were taken from all subjects that met the research criteria until the required number of samples was fulfilled. The inclusion criteria in this study were the two-sample parents were ethnicities included in the scope of the study, were not seriously ill (affected weight) for the past month, had no edema, were not pregnant, had no bone abnormalities, and were willing to participate as respondents in research. The sample size in this study was calculated using the Stanley Lemeshow formula. The estimated weight formula used in this study is based on a pocketbook commonly used in hospitals.

\section{Results}

In Table 1, it can be seen that in male, the largest measurement of actual body weight is found in the Toraja $(58.60 \mathrm{~kg})$ and the lightest is the Bugis $(54.49 \mathrm{~kg})$. Based on the results of the actual UAC measurements found that the greatest results were seen in the Mandar ethnics $(27.237 \mathrm{~cm})$ and the smallest was the Makassar ethnic $(26.531 \mathrm{~cm})$. Based on the ideal body weight, the results of the calculation are most found in the Bugis ethnic $(59.12 \mathrm{~kg})$ and the smallest is the Mandar ethnic $(57.36 \mathrm{~cm})$. Based on the results of the estimated body weight, the greatest results were found in the Toraja $(59.90 \mathrm{~kg}$ ) and the smallest found in the Makassar ethnic (58.217).

In women, the highest measurement of actual body weight was found in the Makassar ethnic $(52.121 \mathrm{~kg})$ and the lightest was the Toraja ethnic $(49.7 \mathrm{~kg})$. Based on the results of the actual UAC measurements found that the greatest results were seen in the Makassar ethnic $(26.17 \mathrm{~cm})$ and the smallest was the Toraja ethnic $(24.7 \mathrm{~cm})$. Based on the ideal body weight, the most calculated results are found in the Bugis ethnic $(48.59 \mathrm{~kg})$ and the smallest is the Mandar ethnic $(47.824 \mathrm{~cm})$. Based on the results of the estimated body weight, the largest results were found in the Bugis ethnic $(49.315 \mathrm{~kg})$ and the smallest one was found in the Toraja ethnic $(46.7 \mathrm{~kg})$.

In Table 2, it can be seen that by using the $100 \%$ UAC standard formula to calculate estimated body weight, it was found that the measurement value of estimated body weight in women differed significantly from the actual weight value $(p<0.05)$. Whereas in men, the measurement value was found to be different in the Makassar and Toraja ethnics, but it was found to be no

Table 1: Characteristic respondents

\begin{tabular}{|c|c|c|c|c|c|c|c|c|}
\hline \multirow[t]{2}{*}{ Measurement component } & \multicolumn{4}{|l|}{ Male } & \multicolumn{4}{|l|}{ Female } \\
\hline & Bugis & Makassar & Mandar & Toraja & Bugis & Makassar & Mandar & Toraja \\
\hline $\mathrm{n}$ & 96 & 62 & 95 & 125 & 92 & 149 & 126 & 151 \\
\hline \multicolumn{9}{|l|}{ Actual weight $(\mathrm{kg})$} \\
\hline Min & 42.9 & 42.4 & 36.6 & 40.40 & 32.4 & 35.2 & 34.2 & 36.6 \\
\hline Max & 81 & 69.7 & 82.6 & 123.50 & 80.5 & 91.5 & 81.6 & 80 \\
\hline SD & 7.063 & 6.25 & 9.22 & 10.42 & 8.768 & 10.028 & 9.614 & 7 \\
\hline Mean & 54.49 & 56.937 & 55.215 & 58.60 & 50.914 & 52.121 & 50.021 & 49.7 \\
\hline \multicolumn{9}{|c|}{ Upper arm circumference actual $(\mathrm{cm})$} \\
\hline Min & 21.8 & 20 & 21 & 19.60 & 20 & 19.8 & 19 & 19.1 \\
\hline Max & 39.5 & 32 & 36 & 38.00 & 35 & 38 & 35.5 & 35.5 \\
\hline SD & 2.536 & 2.394 & 3.087 & 2.99 & 3.277 & 3.56 & 3.785 & 2.4 \\
\hline Mean & 26.54 & 26.531 & 27.237 & 26.97 & 26.055 & 26.173 & 25.969 & 24.7 \\
\hline \multicolumn{9}{|l|}{ Ideal weight (kg) } \\
\hline Min & 47 & 48.5 & 41 & 45.30 & 41.5 & 37 & 38 & 38 \\
\hline $\operatorname{Max}$ & 65.25 & 68.67 & 68.4 & 70.47 & 62.1 & 59.85 & 58.14 & 60.2 \\
\hline SD & 3.409 & 3.554 & 4.355 & 4.40 & 4.518 & 3.084 & 2.935 & 3.75 \\
\hline Mean & 59.12 & 57.74 & 57.366 & 58.50 & 48.59 & 48.036 & 47.824 & 48.5 \\
\hline \multicolumn{9}{|l|}{ Estimated body weight $(\mathrm{kg})$} \\
\hline Min & 44.68 & 45.86 & 35.13 & 41.58 & 32.68 & 33.96 & 34.24 & 32.5 \\
\hline $\operatorname{Max}$ & 82.45 & 74.93 & 78.84 & 97.53 & 75.61 & 71.19 & 68.36 & 78.5 \\
\hline SD & 6.926 & 6.098 & 8.301 & 8.21 & 7.969 & 7.43 & 7.491 & 5.95 \\
\hline Mean & 59.69 & 58.217 & 59.454 & 59.90 & 49.315 & 48.937 & 48.309 & 46.7 \\
\hline
\end{tabular}


Table 2: Comparison of the results of measurements of actual body weight and estimated body weight using several formula in South Sulawesi Ethnics

\begin{tabular}{|c|c|c|c|c|c|c|c|c|c|}
\hline \multirow[t]{3}{*}{ Gender and etnic } & \multicolumn{9}{|c|}{ The formula for percentage of standard upper arm circumference } \\
\hline & \multicolumn{3}{|l|}{$100 \%$} & \multicolumn{3}{|l|}{$90 \%$} & \multicolumn{3}{|l|}{$85 \%$} \\
\hline & $\begin{array}{l}\text { Mean actual } \\
\text { weight }(\mathrm{kg})\end{array}$ & $\begin{array}{l}\text { Mean estimati on } \\
\text { weight }(\mathrm{kg})\end{array}$ & p-values* & $\begin{array}{l}\text { Mean actual } \\
\text { weight }(\mathrm{kg})\end{array}$ & $\begin{array}{l}\text { Mean estimation } \\
\text { weight }(\mathrm{kg})\end{array}$ & p-value * & $\begin{array}{l}\text { Mean mean actual } \\
\text { weigh }(\mathrm{kg})\end{array}$ & $\begin{array}{l}\text { Mean estimation } \\
\text { weight }(\mathrm{kg})\end{array}$ & $p$-value* \\
\hline \multicolumn{10}{|l|}{ Female } \\
\hline Bugis (92) & 50.910 & 45.100 & 0.000 & 50.910 & 50.110 & 0.515 & 50.910 & 53.060 & 0.089 \\
\hline Makassar (149) & 52.120 & 44.128 & 0.000 & 52.121 & 49.032 & 0.003 & 52.210 & 51.916 & 0.845 \\
\hline Toraja (151) & 49.650 & 42.262 & 0.000 & 49.650 & 46.962 & 0.000 & 49.650 & 49.724 & 0.927 \\
\hline Mandar (126) & 50.020 & 43.749 & 0.000 & 50.021 & 48.610 & 0.198 & 50.021 & 51.471 & 0.196 \\
\hline \multicolumn{10}{|l|}{ Male } \\
\hline Bugis (96) & 54.480 & 53.325 & 0.224 & 54.480 & 59.250 & 0.000 & 54.480 & 62.740 & 0.000 \\
\hline Makassar (62) & 56.940 & 51.994 & 0.000 & 56.937 & 57.764 & 0.453 & 56.937 & 61.166 & 0.000 \\
\hline Toraja (125) & 58.600 & 53.711 & 0.000 & 58.601 & 59.678 & 0.360 & 58.601 & 63.189 & 0.000 \\
\hline Mandar (95) & 55.220 & 53.455 & 0.150 & 55.215 & 59.390 & 0.001 & 55.215 & 62.880 & 0.000 \\
\hline
\end{tabular}

different in the Bugis and Mandar ethnics $(p=0.224$ and $p=0.150)$. It appears that the value of the estimated body weight is smaller than the actual weight.

Using the $90 \%$ standard UAC formula to calculate estimated body weight, it was found that the estimated weight values for women were found to be significantly different in the Makassar ethnic $(p=0.003)$ and Toraja $(p=0.000)$. However, the value was found to be no different in the Bugis ethnic $(p=0.515)$ and Mandar ( $p=0.198)$. Whereas in men, the measurement values were found to be significantly different in Bugis $(p=0.000)$ and Mandar ethnics $(p=0.001)$. However, this value was found to be no different in the Makassar ethnic $(p=0.453)$ and Toraja $(p=0.360)$. It appears that the value of the estimated body weight is greater than the actual body weight.

Using the $85 \%$ standard UAC formula to calculate estimated body weight, it was found that the measurement value of estimated body weight in women did not differ significantly in all ethnics, namely Bugis $(p=0.089)$, Makassar $(p=0.845)$, Toraja $(p=0.927)$, and Mandar $(p=0.196)$. However, the value was found to be no different in the Bugis ethnic $(p=0.515)$ and Mandar $(p=0.198)$. Whereas in men, the measurement values were found to be significantly different in Bugis ( $p$ $=0.000)$ and Mandar ethnics $(p=0.001)$. However, this value was found to be no different in the Makassar ethnic $(p=0.453)$ and Toraja $(p=0.360)$. It appears that the value of the estimated body weight is greater than the actual body weight. Whereas in men, it was found that the measurement value of estimated body weight using $85 \%$ standard UAC differed significantly in all terms $(p<0.000)$. It appears that the value of the estimated body weight is greater than the actual body weight.

\section{Discussion}

Differences in body size in various ethnicities are influenced by several factors such as gene and environmental factors. Linasari, who examined differences in Balinese ethnic body proportions and Madurese ethnicity, found that the Madurese were found to be smaller in body size than Balinese ethnicity. Ethnic Madurese apparently have a shorter height, lighter weight, and smaller UAC compared to Balinese, although the difference is not significant [6]. The same was found by Nidiaputri, who looked at a comparison of anthropometry of Indonesian female students based on the three largest ethnics in Indonesia. The study found that the dimensions of Javanese hand lengths were the largest compared to Batak and Sundanese ethnic groups. Meanwhile, the Batak ethnic group has wider and thicker hand dimensions than the Javanese and Sundanese. The study also found that when compared to other countries, such as Bangladesh, Vietnam, Hong Kong, Nigeria and the United Kingdom, the dimensions of Indonesian women tended to be longer and thicker than those of Vietnam and Bangladesh. As for the size of the hand width, Indonesian women have the smallest size of all comparison countries [7].

Anthropometric differences between ethnicities are associated with genetic factors. In addition to environmental influences that affect individual growth, genes affect physical conditions because they are inherited by parents to their offspring biologically. Inherited gene expression and growth patterns are embraced by biological systems that operate in the appropriate environment. This biological system is like the role of genes that regulate the release and regulate the activation of growth hormones [8]. This explanation is reinforced by observations made by Artaria [9]. From the results of research on two different ethnicities, it was seen that the body size of the two ethnic groups began to differ after the age of puberty [9].

In assessing nutritional status, especially in special circumstances, such as in the elderly or patients who cannot stand upright, certain formulas have been prepared using other anthropometric components that are in accordance with the specific conditions. The results show that the results of the estimated anthropometric component calculations are in accordance with the results of the actual measurements, but some are different. Like a study conducted by MY Jung [10], who found that the estimated body weight calculated from the knee height equation was significantly higher than the actual body weight in ethnic Chinese [10]. Similarly, the study conducted by Ariyani found that the UAC threshold 
which has the most optimal value of sensitivity and specificity and positively correlated in Indonesian women is 24.95 or $25 \mathrm{~cm}$. Higher than the standard commonly used is $23.5 \mathrm{~cm}$ [4].

However, there are also studies that find that different anthropometric components can be used to determine nutritional status. Like the study conducted by Mulyasari, who found that the UAC was associated with significant body weight and length of the ulna also significantly associated with height. Thus, the circumference of the upper arm can be used to predict body weight while the length of the ulna can be used to predict height [11].

\section{Recommendation}

From this study, it can be seen that based on the formula commonly used to predict the patient's body weight, if the formula is calculated using the formula $100 \%$ patient UAC (PUAC), then it is suitable for Bugis and Mandar Ethnic men. The use of the formula $90 \%$ PUAC is suitable for ethnic Bugis women and ethnic Mandar and male ethnic Makassarese and ethnic Toraja. The use of the formula $85 \%$ is suitable for women for all ethnicities, namely Bugis, Makassar, Toraja, and Mandar.

\section{Conclusion}

From this study it can be seen that based on the formula commonly used to predict the patient's body weight, if the formula is calculated using the formula 100\% Patient Upper Arm Circumference, then it is suitable for Bugis and Mandar Ethnic men. The use of the formula $90 \%$ Patient Upper Arm Circumference is suitable for ethnic Bugis women and ethnic Mandar and male ethnic Makassarese and ethnic Toraja. The use of the formula $85 \%$ is suitable for women for all ethnicities, namely Bugis, Makassar, Toraja and Mandar.

\section{References}

1. Brian $W$, Douglas $Y$, James $Q$, Matthew $S$. A better way to estimate adult patients' weights. Am J Emerg Med. 2009;27(9):1060-4. PMid:19931751

2. Faculty of Medicine, Hasanuddin University. Wahidin Sudirohusodo Hospital, Secondary Data for SeptemberDecember 2015. , Indonesia: Faculty of Medicine, Hasanuddin University; 2015.

3. Khadivzadeh T. Mid upper arm and calf circumferences as indicators of nutritional status in women of reproductive age. East Mediterr Health J. 2002;8(4-5):612-8.

4. Ogi A. Meaning Daeng In Bugis Culture; 2010. Available from http: //www.rappang.com/2010/02/arti-daeng-dalam-kebulturbugis.html. [Last accessed on 2019 Apr 06].

5. Ogi A. Arti Daeng Dalam Kebudayaan Bugis; 2010. Available from: http://www.rappang.com/2010/02/arti-daeng-dalamkebudayaan-bugis.html. [Last accessed on 2019 Apr 06].

6. Rini L. Perbedaan Pada Proporsi Tubuh Etnis Bali Dengan Etnis Madura di Surabaya Repository. Available from: http://www. unair.ac.id. [Last accessed on 2019 Apr 06]

7. Angela EN. Comparison of Hand Anthropometry of Indonesian Students Based on the Three Largest Tribes in Indonesia. Industrial Engineering Study Program, Department of Mechanical and Industrial Engineering, Faculty of Engineering, Gajah Mada University, Yogyakarta; 2015. https;//doi. org/10.5614/j.ergo.2019.4.1.5

8. Supariasa ID, Bachri B, Ibnu F. Assessment of Nutritional Status. EGC Jakarta; 2002.

9. Artaria MD. The effect of hereditary factors on body proportion. Child Soc Cult Pol. 2013;26:15-24.

10. Jung MY, Chan MS, Chow VS, Chan YT, Leung PF, Leung EM, et al. Estimating geriatric patient's body weight using the knee height caliper and mid-arm circumference in Hong kong Chinese. Asia Pac J Clin Nutr. 2004;13(3):261-4. PMid:15331338

11. Indri M. Upper arm circumference has a meaningful relation to body weight, ulna length is also significantly related to height. Indones Nutr J. 2018;7(1):30-6. 